\title{
The Effect of Managerial Ability on Earnings Classification Shifting and Agency Cost of Iranian Listed Companies
}

\author{
Mohsen Imeni $\mathbb{D}^{1},{ }^{1}$ Mohammad Fallah $(\mathbb{D}),{ }^{2}$ and Seyyed Ahmad Edalatpanah $\mathbb{1 D}^{3}$ \\ ${ }^{1}$ Department of Accounting, Ayandegan Institute of Higher Education, Tonekabon, Iran \\ ${ }^{2}$ Department of Industrial Engineering, Branch of Center Tehran, Azad Islamic University, Tehran, Iran \\ ${ }^{3}$ Department of Applied Mathematics, Ayandegan Institution of Higher Education, Tonekabon, Iran \\ Correspondence should be addressed to Mohammad Fallah; mohammadfallah553@gmail.com
}

Received 14 January 2021; Revised 9 April 2021; Accepted 25 May 2021; Published 4 June 2021

Academic Editor: Junhai Ma

Copyright ( 12021 Mohsen Imeni et al. This is an open access article distributed under the Creative Commons Attribution License, which permits unrestricted use, distribution, and reproduction in any medium, provided the original work is properly cited.

\begin{abstract}
The objective of this study is to examine the relationship between managerial ability and earnings classification shifting of firms listed in the Tehran Stock Exchange (TSE). The paper consists of a sample of 1,875 firm-year observations after applying systematic elimination sampling method during a period of fifteen years, from 2005 to 2019. This study used the multivariate panel data regression for testing the links between variables. The results of this study provide that there is a positive relationship between managerial ability and earnings classification shifting. The obtained results indicate that there is a negative relationship between managerial ability and real earnings management and no relationship between managerial ability and AEM. In addition, managerial ability mitigates the negative effect of earnings management on future firm performance. Furthermore, managerial ability affects its agency cost positively due to the reduction in earnings management. This paper contributes to developing management literature and financial reporting literature. The study focuses on links managerial ability and earnings classification shifting and agency cost in a developing country like Iran, and the results of the paper can fill distance theory and practice by empirical test. Furthermore, the results of this study indicate in an emerging market, namely, Iran, that has a political business environment among the other countries of the Middle East, managerial ability can release Iranian firms on economic sanctions and financial pressures. This paper is the first study of its type in Iran.
\end{abstract}

\section{Introduction}

Today, information plays an important role in economic decision-making, and no doubt, the quality of it, including accuracy in providing it to a wide range of users, can be useful for decision-making. One of the basic financial statements that can solve some of the needs of the users is the income statement, that the final product of this statement is net income [1]. Chen and Howard (2016) believe that the accounting earnings reported in this financial statement can be an important element of information for stakeholders to determine stock prices and evaluate management performance [2], which is consistent with the comments of Ball and Brown (1968) [3]. In addition, based on the positive theory and executive compensation plans, net earnings are very important for managers [4]. Therefore, they may manipulate and manage earnings. Eisenhardt (1989) stated that agency problems arise when managers manipulate the corporate financial information to achieve their private motivations [5]. This creates a conflict of interest between the agent and the principal [6]. Based on agency theory, Jiraporn et al. (2008) assume that the conflicts of agency can drive managers to use the flexibility of accounting procedures [6].

Managerial ability to manage a business firm can be an effective factor in generating earnings and forecasting future earnings [7]. A capable manager is expected to have greater intelligence, monition, and knowledge to understand accounting standards and applying them to better estimate and judge accruals. Overall, capable managers are expected to have a better estimate of accruals, due to their better understanding of the environmental conditions [8]. 
Some researches indicate that managers receive higher compensation and also have a high level of skill and reputation, avoiding earnings management because they do not intend to scratch their reputation $[9,10]$; thus, the conflict of agency is reduced [11]. Research shows such managers can use resources effectively and efficiently [12], and it is expected that higher-ability managers reduce earnings management [13]. These managers can use the company's resources to create higher sales, and under the financial distress conditions, they manage earnings via three strategies: manipulation of real actives, accrual-based earnings management, and classification shifting [8, 12, 14]; to maximize the earnings, they must choose its strategy based on the limited information they are able to obtain [15]. On the other hand, management may show (for reasons such as job security, receiving compensation, increasing the firm value, and other factors) the firm earning more than actual numbers, to provide a good picture of the firm's performance [16]. In other words, the managers to achieve predetermined targets do earnings management. This manager's action causes the reported earnings to be different from the actual earnings of the firm and, as a result, of low quality and it cannot play its role well in economic decisionmaking. McVay (2006) argues that there are three forms of earnings management: Accrual-based Earnings Management (AEM, hereafter), Real Earnings Management (REM, hereafter), and earnings classification shifting. However, the most of the existing works have focused on AEM and REM $[17,18]$.

Often, managers can use all three forms of earnings management to achieve their targets, but their decisions can be determined between different methods based on the costs each earnings management methods [18]. It can be said that the classification shifting is a particular earnings management strategy. Managers move items within the income statement to improve core earnings that is not consistent with economic reality. Thus, classification shifting is defined as "the deliberate misclassification of items within the income statement" [17]. It seems that managers of these firms, despite shifting the position of items within the income statement, will try to maximize their utility. However, this is not converging with the economic reality of firms.

The previous studies [19-21] show that when a form of earnings management has to be more expensive, managers use alternative forms of earnings management to achieve their reporting goals. Therefore, this study investigates the relationship between managerial ability and earnings management through the earnings classification shifting. In addition, it seems earnings management can lead to conflict in the interests of between managers and owners. It is expected that capable managers reduce the negative effect of this relation $[11,22]$.

The primary objective of this study is to contribute to the literature by examining the ability of managers and earnings management in Iran as one of the emerging markets. In recent years, economic and financial systems have expanded [23]. Therefore, an economic environment like Iran can be interesting for the following reasons: First, given the lack of analysts' earnings forecast and other mechanisms, financial statements are the only major source of information for investors in this capital market; therefore, most transactions in this market of capital are made based on accounting data such as earnings. Thus, the importance of earnings for stock pricing is very high. This important role of earnings creates an incentive for managers to manage earnings. In particular, findings of this research can contribute to standards regulators of accounting in emerging markets. Second, due to absence of strong supervisory systems in Iran (similar to other emerging countries in the Middle East) in comparison with the developed capital markets, the managers have relatively high authority to provide the financial reports [24], and this may cause an agency problem; hence, managers can be opportunistic and manage their earnings. Therefore, examining earnings management in an economic environment such as Iran as one of the emerging markets could provide appropriate evidence for other emerging countries. Third, the market of Iranian capital is in terms of infrastructure (such as financial reporting standards and the basis of the markets) comparable to other developing capital markets. Thus, the findings of this research can be generalisable and useful to these markets.

Furthermore, this study contributes to the development of theoretical literature in this area of managerial ability and earnings management. The literature linking between the managerial ability and agency costs is also investigated.

This paper is structured as follows. In Section 2, we discuss the background of the earnings management, describe managerial ability as influenced by earnings management, and develop our hypotheses of the expected relation between managerial ability and earnings classification shifting. In Section 3, we describe the data and sample, methodology, and variable definitions. Section 4 presents our empirical findings. In Section 5, the results of several additional robustness tests have been presented. The final section presents the summary, conclusion, limitations, and suggestions for future research.

\section{Literature Review and Hypothesis Development}

Earnings management is one of the dominant patterns in accounting researches that its roots have to be explored in the choice of accounting procedure. In this regard, two patterns of earnings management through accruals and real activities manipulation are most studied $[17,18,25,26]$. However, the use of each of these methods has limitations in both time and cost [21]. McVay (2006) provided other patterns of earnings management, namely, classification shifting. This method occurs within the income statement. Classification shifting is a tool of earnings management that used to shift items in the income statement, while net income value does not change [17]. Thus, classification shifting is often disguised as a practice of standard accounting in financial statements, although, it is within the boundaries of accounting frameworks of regulatory, in practice, it is difficult to detect [26].

When choosing any of these earnings management methods by managers, they must consider the benefits and costs of each of these methods. Research indicates that these 
patterns are used as alternatives to each other [18, 27]. Conventionally, classification shifting increase the core earnings by changing the core costs to noncore costs while keeping the earnings at the same level. McVay (2006) believes that classification shifting is "deliberate classification of the items of the income statement" [17], and since managers shift items between different groups, therefore the amount of net income will not be affected by these changes.

Accounting standards based on the legal framework give managers a great authority to create the transaction for the financial reports. Hence, expected capable managers, due to being more knowledgeable about the firm and the industry, are more able to use earnings management [13]. In addition, results of prior research show that there is a different relationship between managers' ability and earnings management through its all patterns [12-14]. Taken together, we do not have a special directional prediction and state the following null hypothesis:

H1. There is no relation between managerial ability and earnings classification shifting.

Previous studies on managerial ability find that highability managers can have a positive impact on firms' current and future performance (e.g., [12-14]) and there is a negative association between managerial ability and earnings management (e.g., $[12,28,29]$ ). Hence, high-ability managers can reduce the negative impact of earnings management and improve future performance. Thus, we propose the following hypothesis:

H2. Ceteris paribus, managerial ability mitigates the negative effect of earnings management through classification shifting on future firm performance.

Jiraporn et al. (2008) find that earnings management reduces cost agency [6], and Man et al. (2018) suggest earnings management is positively associated with agency conflict [22]; thus, the relationship between both variables is vague because managers with different goals do earnings management.

Due to information asymmetry between the managers and the shareholders, increasing the earnings with opportunistic targets increases the agency cost. Moreover, the results of prior research indicate that high-ability managers could reduce agency cost [11]. Thus, we propose the following hypothesis:

H3. Ceteris paribus, a firm's managerial ability affects negatively its agency cost.

\section{Empirical Methodology}

3.1. Data and Sample Description. The sample for analysis is composed of 1,875 firm-year observations for the years 2005 to 2019. However, the companies that had the following criteria were exerted and selected: It must have been listed before the end of 2005 in Tehran Stock Exchange. Selected companies must have not been part of the investment, banks, insurance, and financial companies. Selected companies must have not changed the financial year during the designated period. After exerting these criteria, the sample study was reduced to 125 companies.

3.2. Models. To test the relation between earnings management by classification shifting and managerial ability, we estimate the following Ordinary Least Squares (OLS) model:

$$
\begin{aligned}
\mathrm{UCE}_{i, t}= & \beta_{0}+\beta_{1} \mathrm{MA}_{i, t}+\beta_{2} \mathrm{CFO}_{i, t}+\beta_{3} \mathrm{OPCYCLE}_{i, t} \\
& +\beta_{4} \mathrm{LEV}_{i, t}+\beta_{5} \mathrm{ROA}_{i, t}+\beta_{6} \mathrm{HIGHNOA}_{i, t} \\
& + \text { Year Effect }+ \text { Industry Effect }+\varepsilon_{i, t} .
\end{aligned}
$$

\subsection{Variable Definitions}

3.3.1. Dependent Variable (Classification Shifting). Following Wu [27], we employ McVay's (2006) [17] model to estimate the Expected Core Earnings (ECE). The McVay model is defined as follows:

$$
\begin{aligned}
\mathrm{CE}_{i, t}= & \beta_{0}+\beta_{1} \mathrm{CE}_{i, t-1}+\beta_{2} \mathrm{ATO}_{i, t}+\beta_{3} \mathrm{ACC}_{i, t-1}+\beta_{4} \mathrm{ACC}_{i, t} \\
& +\beta_{5} \% \Delta \mathrm{SALES}_{i, t}+\beta_{6} \Delta \mathrm{NEG}-\mathrm{SALES}_{i, t}+\varepsilon_{i, t} .
\end{aligned}
$$

Then, we test the above model and obtain the coefficients of $\beta_{i}(i=0,1, \ldots, 6)$ to calculate Expected Core Earnings (ECE). Finally, unexpected core earnings (UCE) is calculated by subtracting the core earnings (CE) from the estimated core earnings (ECE):

$$
\mathrm{UCE}_{i, t}=\mathrm{CE}_{i, t}-\mathrm{ECE}_{i, t} .
$$

Core earnings $\left(\mathrm{CE}_{i, t}\right)$ is defined as sales minus COGS and selling, general and administrative expenses scaled by sales, $\mathrm{CE}_{i, t-1}$ is lagged core earnings (to control for earnings persistence over time, and it is expected to be a positive sign), and $\mathrm{ATO}_{i, t}$ is asset turnover ratio (total sales divided by average net operating assets). The average net operating asset is also the difference between an operating asset and operating debt of the current year and the previous year divided by 2 . Operating assets are defined as the difference between total assets and sum cash and short-term investment [30]. Also, operating debt is different total assets, total debt, and the book value of equity; prior research (e.g., [31]) demonstrates that there is a negative relationship between ATO and profit margin. Since the profit margin is used to calculate the core earnings, this is expected to be a negative sign. Accruals $\left(\mathrm{ACC}_{i, t-1}\right)$ is different between operating earnings and cash flow from operations scaled by sales. Sloan (1996) believes that there is a relationship between accruals with future performance [32]; and accruals component of earnings has less persistence than the cash component of earnings. Since higher accruals have less persistence, this is expected to be a negative sign. DeAngelo et al. find that high performance is associated with an increase in accruals and vice versa [33]. To control the effect of this, variable $A_{C C}$ it, is added to the model, which is expected to be a positive sign. To control the effect of sales growth, $\% \Delta$ SALES $_{\mathrm{i}, \mathrm{t}}$ is added to 
the model. The percentage of change in sales results from the difference between the current year's sales and the previous year's sales divided by the previous year's sales. $\triangle \mathrm{NEG-}$ SALES $_{\mathrm{i}, \mathrm{t}}$ is a dummy variable, 1 if different between current year sales and the previous year sales is negative, and otherwise 0 .

\subsubsection{Independent Variable (Managerial Ability Measure} $(M A))$. As previously mentioned, management must be able to optimally utilize the resources of the company and use these resources to maximize returns and revenues [34]. Therefore, this variable is obtained by calculating the firm's resource efficiency. In the present study, for measuring the managerial ability (MA, hereafter), consistent with Luo and Zhou [35], we use a DEA-based method developed by Demerjian et al. [13]. In this model (4), using the efficiency of the firm as a dependent variable and controlling the inherent characteristics of the firm, the managerial ability will be calculated. In this research, the two-step method from Demerjian et al. (2012) is used to obtain a manager-level
DEA score. In the first step, we capture a measure of efficiency by solving an optimization problem using (DEA). For achieving this purpose, maximize an output variable based on four input variables. Sales is used as an output variable and four input variables are used as follows: (1) cost of goods sold (CGS), (2) net property, plant, and equipment (PPE), (3) selling, general, and administrative costs (SG\&A), (4) logarithm natural of intangible assets, (5) research and development costs (R\&D), and (6) goodwill. The efficiency score includes both manager and firm characteristics. Data envelopment analysis (DEA) provides an efficient border for firms. The efficiency measure $(\theta)$ produced by the DEA is a value between 0 and 1 [36]. Companies with a performance score of 1 are those that are highly efficient and those with a score of less than one are below the performance threshold and must reach the bottom by reducing costs or increasing revenues.

As mentioned above, to measure the efficiency of firms, we use the following formula of Demerjian et al. [13]:

$$
\operatorname{Max}_{v} \theta=\frac{\text { Sales }}{v_{1} \mathrm{CGS}+v_{2} \mathrm{SG} \& A+v_{3} \mathrm{PPE}+v_{4} \operatorname{InTAN}+v_{5} R \& D+v_{6} \text { Goodwill }}
$$

The purpose of calculating firm efficiency is to measure managerial ability. Hence, efficiency-related calculations are involved with the inherent characteristics of the firms. For this reason, measuring the ability of managers cannot be accurate. Demerjian et al. (2012) [13] believe that to control the inherent characteristics of the firms in the model (4), the firms' efficiency must be divided into two parts. It means that the efficiency is divided based on firm's inherent characteristics and managerial ability. In this regard, a regression shows the relationship between the Firm Efficiency (FE) and the firm characteristics that is used to describe the model (5):

$$
\mathrm{FE}=\alpha_{0}+\alpha_{1} \mathrm{LNTA}+\alpha_{2} \mathrm{MS}+\alpha_{3} \mathrm{PFCF}+\alpha_{4} \mathrm{LnAge}+\delta,
$$

where LNTA is the natural logarithm of the book value of total assets, MS (market share) is the ratio of firm sales to total sales in the same industry, PFCF (positive free cash flow) is a dummy variable that is one if free cash flow is positive, otherwise 0 , and LnAge is the natural logarithm of firm age. Therefore, to calculate the Free Cash Flow (FCF), we have

$$
\mathrm{FCF}_{i, t}=\frac{\left(\mathrm{INC}_{i, t}-\mathrm{TAX}_{i, t}-\mathrm{INTEP}_{i, t}-\mathrm{CSDIV}_{i, t}\right)}{A_{i, t-1}},
$$

where INC is the operating earnings before depreciation, TAX is the total tax paid, INTEP is interest expense paid, CSDIV is common stockholders' dividends, and $A$ is total assets. In addition, the residuals of model (5) identify the level of managerial efficiency, and this is an indicator of managerial ability [13].
3.3.3. Control Variables. The control variables in this paper are leverage, cash flow from the operation, profitability, operating cycle, and high level of net operating assets. The definitions of these control variables are listed in Table 1. Lev is defined as the ratio of total debt to the total assets [37]. $\mathrm{CFO}$ is the ratio of cash flow from operation to the total assets. ROA is as an indicator of profitability. ROA is defined as net income divided by the average of the total assets [38]. The operating cycle is defined based on Dechow as the period of inventory turnover plus accounts receivable period minus the period of creditor's payment period at the beginning of the year [39]. High net operating assets, which is an indicator variable that equals one if the net operating assets (i.e., shareholders' equity less cash and short-term investment plus total debt) at the beginning of the year divided by lagged sales, are above the median of the corresponding industry-year, and zero otherwise [21].

\section{Empirical Results}

4.1. Descriptive Statistics. We provide in Table 2 the descriptive statistics of variables for the analysis: dependent variables (UCE); independent variable (MA); and control variables (OPCYCLE, ROA, LEV, and CFO).

The results of Table 2 show that the average ability of managers is equal to $1 \%$. Also, the average efficiency of the firms is $41 \%$, and the ratio of operating cash flow to total assets is $13 \%$. On average, $63 \%$ of the firm's assets are financed by debts. Net income on average is 12 percent of the firm's assets. The mean operating cycle also is equal to 0.0009 . 
TABLE 1: Variable definition.

\begin{tabular}{|c|c|}
\hline $\begin{array}{ll}\mathrm{CE}_{i, t} \\
\mathrm{CE}\end{array}$ & $\begin{array}{c}\text { A core earnings is defined as sales minus COGS and selling, general and administrative expenses scaled by sales } \\
\text { Lagged core earnings }\end{array}$ \\
\hline $\mathrm{ATO}_{i, t}$ & Asset turnover ratio (total sales divided by average net operating assets) \\
\hline $\mathrm{ACC}_{t}$ & Different between operating earnings and cash flow from operations scaled by sales \\
\hline $\mathrm{ACC}_{t-1}$ & Lagged accruals $\left(\mathrm{ACC}_{t}\right)$ \\
\hline$\% \Delta$ SALES $_{t}$ & The percentage of change in sales \\
\hline$\Delta \mathrm{NEG}-\mathrm{SALES}_{t}$ & $\triangle \mathrm{NEG}-\mathrm{SALES}_{t}$ is a dummy variable, 1 if different between current year sales and the previous year sales is negative and \\
\hline Lev & The ratio of total debt to the total assets \\
\hline $\mathrm{CFO}$ & The ratio of cash flo \\
\hline ROA & The net income divided by a \\
\hline Operating cycle & $\begin{array}{r}\text { The period of inventory turnover plus accounts receivable per } \\
\text { beginning of }\end{array}$ \\
\hline HighNOA & $\begin{array}{l}\text { HighNOA is a dummy variable equal to } 1 \text { if the net ope } \\
\text { investment plus total debt) at the beginning of the year } \mathrm{d} \\
\text { industry-ye }\end{array}$ \\
\hline $\mathrm{AC}$ & The costs of the agency to ca \\
\hline BIG & BIG is a dummy variable, and it is 1 if $t$ \\
\hline AEM & $\begin{array}{c}\text { The abnormal level discretionary accruals, derived from the residuals of the Dechow et al.'s (1995) model. This model is } \\
\text { represented in model (12) }\end{array}$ \\
\hline REM & $\begin{array}{l}\text { The abnormal level of cash flows from operations, derived from the residuals of model ( } 8) \text {. The abnormal level of } \\
\text { production costs, derived from the residuals of model }(9) \text {. The abnormal levels of discretionary expenditures, derived } \\
\text { from the residuals of model }(10) \text {. REM is equals }(-1 * \text { abnormal level of cash flows from operations) +abnormal level of } \\
\text { production costs+ }(-1 * \text { abnormal levels of discretionary expenditures). This model is represented in model (11) }\end{array}$ \\
\hline LNTA & LNTA is the natural logaritl \\
\hline MS & Market share is the ratio of firm sales to total sales in the same industry \\
\hline LnAge & LnAge is the natural logarithm of firm age \\
\hline PFCF & $\begin{array}{l}\text { Positive free cash flow is a dummy variable that is one if free cash flow is positive, otherwise } 0 \\
\qquad \mathrm{FCF}_{i t}=\left(\mathrm{INC}_{i t}-\mathrm{TAX}_{i t}-\mathrm{INTEP}_{i t}-\mathrm{CSDIV}_{i t} / A_{i, t-1}\right. \\
\text { where FCF is free cash flow; INC operating earnings before depreciation; TAX is the total tax paid; INTEP interest } \\
\text { expense paid; CSDIV is common stockholders' dividends; and } A \text { is total assets }\end{array}$ \\
\hline
\end{tabular}

Table 2: Descriptive statistics.

\begin{tabular}{|c|c|c|c|c|c|c|}
\hline Variable & Symbol & Mean & Median & Min & $\operatorname{Max}$ & Std. dev. \\
\hline Managerial ability & MA & -0.0115 & 0.0435 & -0.7425 & 0.8048 & -0.3354 \\
\hline Unexpected core earnings & UCE & 0.0155 & 0.0079 & -.9358 & 0.8615 & 0.1199 \\
\hline Firm efficiency & FE & 0.4108 & 0.4706 & 0 & 0.95 & 0.2853 \\
\hline The natural logarithm of total assets & LNTA & 13.622 & 13.4353 & 9.7973 & 19.6455 & 1.5280 \\
\hline Market share & MS & 0.0073 & 0.0028 & 0.0001 & 0.2634 & 0.0137 \\
\hline The natural logarithm of firm life & LnAge & 3.3058 & 3.3639 & 1.9183 & 4.2766 & 0.5039 \\
\hline Cash flow from operation & $\mathrm{CFO}$ & 0.1387 & 0.1161 & -0.6150 & 0.6036 & 0.1694 \\
\hline Leverage & LEV & 0.6271 & 0.6414 & 0.0901 & 2.0775 & 0.2069 \\
\hline Profitability & ROA & 0.1244 & 0.0997 & -0.4527 & 0.8947 & 0.1473 \\
\hline Operating cycle & OPCYCLE & 0.0009 & 0.0003 & -0.003 & 0.0334 & 0.0024 \\
\hline
\end{tabular}

Descriptive statistics for the dummy variable

Net operating assets (NOA)

Positive free cash flow (PFCF)

Num. (1) $47 / 6 \%$ $46 / 1 \%$
Num. (0)

$\begin{array}{cc}52 / 4 \% & 981 \\ 53 / 9 \% & 1010\end{array}$

4.2. Pearson's Correlations. In Table 3, we provide Pearson's correlations between the variables used in our regression analyses.

Table 3 shows the Pearson correlation matrix between the variables used in the previous model. UCE is negatively correlated with MA, LEV, and OPCYCLE. Also, UCE is positively correlated with CFO and ROA. Correlation is significant at the 0.01 and 0.05 level.

\section{Results}

Panel 1 of Table 4 presents the results of testing of the first hypothesis. We use model (1) to test the relation between managerial ability and earnings classification shifting. This table presents the regression results of model (1). Also, all variables are defined in Table 1 . The results indicate that there is a positive relationship between managerial ability 
TABle 3: Pearson's correlation matrix.

\begin{tabular}{|c|c|c|c|c|c|c|c|}
\hline & UCE & MA & $\mathrm{ROA}$ & OPCYCLE & LEV & HIGHNOA & $\mathrm{CFO}$ \\
\hline UCE & 1 & & & & & & \\
\hline MA & $0.071^{*}$ & 1 & & & & & \\
\hline $\mathrm{ROA}$ & $0.434^{*}$ & $0.135^{*}$ & 1 & & & & \\
\hline OPCYCLE & $-0.065^{* *}$ & -0.017 & $-0.064^{* *}$ & 1 & & & \\
\hline LEV & $-0.155^{* *}$ & -0.035 & $-0.531^{* *}$ & $-0.093^{* *}$ & 1 & & \\
\hline HIGHNOA & 0.024 & -0.034 & $-0.327^{* *}$ & 0.033 & $0.359^{* *}$ & 1 & \\
\hline $\mathrm{CFO}$ & $0.529^{* *}$ & 0.007 & $0.569^{* *}$ & $-0.118^{* *}$ & $-0.270^{* *}$ & $-0.207^{* *}$ & 1 \\
\hline
\end{tabular}

${ }^{*} p<0.01 .{ }^{* *} p<0.05$.

TABLE 4: The relation between managerial ability and earnings classification shifting ( $\mathrm{H} 1)$, and future performance and impact interaction its earnings management $(\mathrm{H} 2)$.

\begin{tabular}{|c|c|c|c|c|c|c|c|}
\hline $\begin{array}{l}\text { Independent variable } \\
\text { Panel } 1\end{array}$ & $\begin{array}{c}\text { UCE } \\
\text { Coeff. } \\
t \text {-stat. }\end{array}$ & $\begin{array}{c}\text { Independent variable } \\
\text { Panel } 2\end{array}$ & $\begin{array}{c}\mathrm{ROA}_{\mathrm{t}+1} \\
\text { Coeff. } \\
t \text {-stat. }\end{array}$ & $\begin{array}{c}\mathrm{CFO}_{\mathrm{t}+1} \\
\text { Coeff. } \\
t \text {-stat. }\end{array}$ & $\begin{array}{c}\text { Independent variable } \\
\text { Panel } 3\end{array}$ & $\begin{array}{c}\mathrm{ROA}_{\mathrm{t}+1} \\
\text { Coeff. } \\
t \text {-stat. }\end{array}$ & $\begin{array}{c}\mathrm{CFO}_{\mathrm{t}+1} \\
\text { Coeff. } \\
t \text {-stat. }\end{array}$ \\
\hline Constant & $\begin{array}{c}-0.099^{* * *} \\
(-8.710)\end{array}$ & Constant & $\begin{array}{c}0.039^{* * *} \\
(3.054)\end{array}$ & $\begin{array}{c}0.050^{* * * *} \\
(2.933)\end{array}$ & Constant & $\begin{array}{c}0.035^{* * *} \\
(2.718)\end{array}$ & $\begin{array}{c}0.065^{* * *} \\
(3.691)\end{array}$ \\
\hline MA & $\begin{array}{c}0.020^{* *} \\
(2.286)\end{array}$ & MA & $\begin{array}{c}0.046^{* * * *} \\
(2.836)\end{array}$ & $\begin{array}{c}0.074^{* * *} \\
(3.374)\end{array}$ & MA & $\begin{array}{c}0.026^{* * *} \\
(2.642)\end{array}$ & $\begin{array}{c}0.044^{* *} \\
(3.282)\end{array}$ \\
\hline ROA & $\begin{array}{c}0.192^{* * *} \\
(8.010)\end{array}$ & UCE & $\begin{array}{l}-0.020^{* *} \\
(-3.386)\end{array}$ & $\begin{array}{l}-0.009 \\
(-1.081)\end{array}$ & REM & $\begin{array}{l}-0.029^{*} \\
-(1.683)\end{array}$ & $\begin{array}{c}-0.072^{* * *} \\
(-3.058)\end{array}$ \\
\hline OPCYLCE & $\begin{array}{c}-8.204^{* * *} \\
(-6.276)\end{array}$ & $\mathrm{MA} \times \mathrm{UCE}$ & $\begin{array}{c}0.032 \\
(-1.541)\end{array}$ & $\begin{array}{l}0.055^{*} \\
(-1.951)\end{array}$ & $\mathrm{MA} \times \mathrm{REM}$ & $\begin{array}{c}0.041 \\
(1.391)\end{array}$ & $\begin{array}{l}0.0531 \\
(1.332)\end{array}$ \\
\hline LEV & $\begin{array}{c}0.059^{* * *} \\
(3.731)\end{array}$ & ROA & $\begin{array}{c}0.346^{* * *} \\
(12.73)\end{array}$ & $\begin{array}{c}0.186^{* * *} \\
(5.057)\end{array}$ & ROA & $\begin{array}{l}0.368^{* * *} \\
(13.417)\end{array}$ & $\begin{array}{c}0.174^{* * *} \\
(4.721)\end{array}$ \\
\hline HIGHNOA & $\begin{array}{c}0.032^{* * * *} \\
(6.083)\end{array}$ & OPCYLCE & $\begin{array}{c}1.677 \\
(1.143)\end{array}$ & $\begin{array}{c}1.574 \\
(0.793)\end{array}$ & OPCYLCE & $\begin{array}{c}1.380 \\
(0.940)\end{array}$ & $\begin{array}{c}1.388 \\
(0.701)\end{array}$ \\
\hline \multirow[t]{3}{*}{$\mathrm{CFO}$} & $\begin{array}{c}0.330^{* * *} \\
(2.820)\end{array}$ & LEV & $\begin{array}{c}0.029 \\
(1.638)\end{array}$ & $\begin{array}{c}0.091^{* * *} \\
(3.808)\end{array}$ & LEV & $\begin{array}{l}0.032^{*} \\
(1.850)\end{array}$ & $\begin{array}{c}0.093^{* * *} \\
(3.913)\end{array}$ \\
\hline & & HIGHNOA & $\begin{array}{c}0.001 \\
(0.218)\end{array}$ & $\begin{array}{c}-0.003 \\
(-0.472)\end{array}$ & HIGHNOA & $\begin{array}{c}0.003 \\
(0.587)\end{array}$ & $\begin{array}{c}-0.001 \\
(-0.186)\end{array}$ \\
\hline & & $\mathrm{CFO}$ & $\begin{array}{c}0.075^{* * *} \\
(3.659)\end{array}$ & $\begin{array}{c}0.024 \\
(0.874)\end{array}$ & $\mathrm{CFO}$ & $\begin{array}{c}0.135^{* * *} \\
(4.678)\end{array}$ & $\begin{array}{l}-0.056 \\
(-1.434)\end{array}$ \\
\hline Year effect & Yes & Year effect & Yes & Yes & Year effect & Yes & Yes \\
\hline Industry effect & Yes & Industry effect & Yes & Yes & Industry effect & Yes & Yes \\
\hline Adjusted $R^{2}$ & 0.42 & & 0.51 & 0.32 & & 0.51 & 0.32 \\
\hline$F$-stat. & 11.454 & & 16.28 & 7.84 & & 16.13 & 7.91 \\
\hline Prob. (F-stat.) & 0.000 & & 0.000 & 0.000 & & 0.000 & 0.000 \\
\hline D-W stat. & 1.73 & & 1.81 & 1.86 & & 1.89 & 1.91 \\
\hline
\end{tabular}

Respectively, symbols ${ }^{*},{ }^{* *}$, and ${ }^{* * *}$ denote statistical significance at $0.1,0.05$, and 0.01 .

and earnings classification shifting. In other words, highability managers due to recognition and understanding in meso/macroeconomic conditions [8], achieve the target earning [14].

5.1. Managerial Ability, Earnings Management, and Future Performance. Following prior research [20, 28, 29, 40], earning management has the negative consequences on future performance, especially real earnings management. Anjum et al. (2012) found that there is a negative relationship between earnings management and performance in Pakistan [41]. Purkayastha (2013) used ROA as a measure of firm performance [42]; also, Huang and Sun (2017) believe $\mathrm{CFO}$ and ROA are an indicator of firm performance [12]. We examine model (6) using UCE/REM and analyze the coefficient on the interaction term of $\mathrm{MA} * \mathrm{UCE}$ in panel 2 and $\mathrm{MA} * \mathrm{REM}$ in panel 3 of Table 4 .

$$
\begin{aligned}
\text { future performance }_{i, t+1}= & \beta_{0}+\beta_{1} \mathrm{MA}_{i, t}+\beta_{2} \mathrm{UCE}_{i, t} \\
& +\beta_{3} \mathrm{MA}_{i, t} \times \mathrm{UCE}_{i, t}+\beta_{4} \mathrm{REM}_{i, t} \\
& +\beta_{5} \mathrm{MA}_{i, t} \times \mathrm{REM}_{i, t}+\beta_{6} \mathrm{CFO}_{i, t} \\
& +\beta_{7} \mathrm{OPCYCLE}_{i, t}+\beta_{8} \mathrm{LEV}_{i, t} \\
& +\beta_{9} \mathrm{ROA}_{i, t}+\beta_{10} \mathrm{HIGHNOA}_{i, t} \\
& + \text { year effect }+ \text { industry effect }+\varepsilon_{i, t} .
\end{aligned}
$$

The findings of panels $\mathrm{A}$ and $\mathrm{B}$ show that the managerial ability is positively related to $\mathrm{ROA}_{t+1}$ and $\mathrm{CFO}_{\mathrm{t}+1}$, and also UCE and REM are negatively related to $\mathrm{ROA}_{t+1}$ and $\mathrm{CFO}_{\mathrm{t}+1}$. These results are consistent with prior literature on earnings management and managerial ability $[12,13]$. 
Furthermore, we find a significant positive relation between MA×UCE and MA×REM, or $\mathrm{ROA}_{\mathrm{t}+1}$ and $\mathrm{CFO}_{\mathrm{t}+1}$. Thus, we may indicate that higher-ability managers can reduce the negative influence of earnings management; see Table 4.

The results of Table 4 show that high-ability managers have a positive effect on profitability and cash flow in future periods and earnings management through real activities and earnings shifting classification has a negative effect on profitability and cash flow in future periods. In addition, the results indicate that high-ability managers cannot mitigate the effects of earnings management through real activities and earnings classification shifting.

5.2. Managerial Ability, Earnings Management, and Agency Cost. High-ability managers can use the resources to achieve the target earnings. Hence, earnings management increases agency costs [22]. Therefore, it is expected that there is a negative relationship between managers' ability and agency costs [11], and high-ability managers mitigate a negative impact.

$$
\begin{aligned}
\mathrm{AC}_{i, t}= & \beta_{0}+\beta_{1} \mathrm{MA}_{i, t}+\beta_{2} \mathrm{UCE}_{i, t}+\beta_{3} \mathrm{MA}_{i, t} \times \mathrm{UCE}_{i, t} \\
& +\beta_{4} \mathrm{CFO}_{i, t}+\beta_{5} \mathrm{OPCYCLE}_{i, t}+\beta_{6} \mathrm{LEV}_{i, t} \\
& +\beta_{7} \mathrm{ROA}_{i, t}+\beta_{8} \mathrm{BIG}_{i, t}+\text { Year Effect } \\
& + \text { Industry Effect }+\varepsilon_{i, t} .
\end{aligned}
$$

Ang et al. (2000) have reported the ratio of operating expenses to net sales as a criterion for measuring costs of the agency, and the lower this ratio, the lower the cost of the agency [43]. Also, BIG is a dummy variable, and it is 1 if the firm audited by audit organization and 0 otherwise. The results are shown in panel A of Table 5.

The results indicate that high-ability managers reduce agency costs. The results of this study are consistent with the results of Bhojraj and Sengupta (2003) [11]. Managers with high-performance ability try to well reveal their good performance. This reduces information asymmetry; thus, agency costs will be reduced. Disclosure of financial information is one of the most important tools for monitoring managers to be more accountable [44]. Investors seek highquality disclosure that reduces information asymmetry between investors and managers [45].

In addition, earnings management increases agency costs that the results are consistent with Man et al. (2018) [22], and managerial ability mitigates the impact of earnings management (classification shifting) on agency costs.

\section{Additional Test}

6.1. Earnings Management Metrics. In this study, two other criteria for calculating earnings management, namely, the manipulation of real activities and accrual-based earnings management, were used to reexamine the relationship between CEO ability and other earnings management criteria.
6.1.1. Real Earnings Management (REM). In this research, Roychowdhury's (2006) model is used to calculate the manipulation of real activities (real earnings management) [28], which will be discussed in detail below.

Model (8) for estimating the abnormal level of cash flows from operations is

$$
\frac{\mathrm{CFO}_{i t}}{A_{i, t-1}}=\alpha_{0}+\alpha_{1} \frac{1}{A_{i, t-1}}+\beta_{1} \frac{S_{i t}}{A_{i, t-1}}+\beta_{2} \frac{\Delta S_{i t}}{A_{i, t-1}}+\varepsilon_{i t},
$$

where CFO is cash flows from operations, $S$ and $\Delta S$ are sales and change in sales $\left(\Delta S_{\mathrm{t}}=S_{t}-S_{t-1}\right)$, and $A_{i, t-1}$ are lagged total assets. The predicted value of CFO is normal cash flows, and the estimated residual is the abnormal cash.

The second model for estimating the abnormal level of production costs is

$$
\frac{\mathrm{PROD}_{i t}}{A_{i, t-1}}=\alpha_{0}+\alpha_{1} \frac{1}{A_{i, t-1}}+\beta_{1} \frac{S_{i t}}{A_{i, t-1}}+\beta_{2} \frac{\Delta S_{i t}}{A_{i, t-1}}+\beta_{3} \frac{\Delta S_{i, t-1}}{A_{i, t-1}}+\varepsilon_{i t} .
$$

Production costs (PROD) are defined as the sum of the cost of goods sold (COGS) and the change in inventory during the year $\left(\mathrm{PROD}_{\mathrm{t}}=\mathrm{CGS}_{\mathrm{t}}+\Delta \mathrm{INV}_{\mathrm{t}}\right)$. In addition, $\Delta$ Sales $_{\mathrm{t}-1}$ is $S_{\mathrm{t}-1}-S_{\mathrm{t}-2}$.

The third model estimates the abnormal levels of discretionary expenditures:

$$
\frac{\mathrm{DISX}_{i t}}{A_{i, t-1}}=\alpha_{0}+\alpha_{1} \frac{1}{A_{i, t-1}}+\beta_{1} \frac{S_{i, t-1}}{A_{i, t-1}}+\varepsilon_{i t} .
$$

DISX is equal to the sum of selling, general, administrative, and R\&D expenses. After determining the number of abnormal levels of real activity manipulation of each of the above models, according to Cohen et al., calculate the real earnings management as follows [20]:

$$
\begin{aligned}
\text { REM }= & (-1 * \text { abnormal level of cash flow from operations }) \\
& + \text { abnormal level of production cost }+ \\
& (-1 * \text { abnormal level of discretionary expenditures }) .
\end{aligned}
$$

Cohen et al., Zang, and Ghaleb et al. believe that the larger calculated values indicate greater earnings management $[20,21,46]$.

6.1.2. Accrual-Based Earnings Management (AEM). For the calculation of earnings management, there are available different models. In the present study, we use the model of Dechow et al. (1995) [47], which is stated in model (13):

$$
\frac{\mathrm{TACC}_{i t}}{A_{i, t-1}}=\alpha_{0}+\alpha_{1} \frac{1}{A_{i, t-1}}+\alpha_{2} \frac{\Delta S_{i t}-\Delta R E C_{i t}}{A_{i, t-1}}+\alpha_{3} \frac{P P E_{i t}}{A_{i, t-1}}+\varepsilon_{i t} .
$$

The higher values of AEM indicate a higher-degree of accrual-based earnings management to increase earnings. This model separates accruals into discretionary accruals 
TABLE 5: The relation between managerial ability and agency cost (H3) in Panel A and reestimates the first hypothesis using model (1) in Panel B.

\begin{tabular}{|c|c|c|c|c|c|c|}
\hline \multicolumn{2}{|c|}{ Panel A } & \multicolumn{3}{|c|}{ Panel B } & \multicolumn{2}{|c|}{ Panel C } \\
\hline $\begin{array}{l}\text { Dependent variable } \\
\text { Variables }\end{array}$ & $\begin{array}{c}\text { Agency cost (AC) } \\
\text { Coeff. } \\
t \text {-stat. }\end{array}$ & & $\begin{array}{l}\text { REM } \\
\text { Coeff. } \\
t \text {-stat. }\end{array}$ & $\begin{array}{l}\text { AEM } \\
\text { Coeff. } \\
t \text {-stat. }\end{array}$ & & $\begin{array}{l}\text { UCE } \\
\text { Coeff. } \\
t \text {-stat. }\end{array}$ \\
\hline MA & $\begin{array}{c}-0.033 \\
-8.794^{* * *}\end{array}$ & MA & $\begin{array}{c}-0.031 \\
-2.274^{* *}\end{array}$ & $\begin{array}{l}0.008 \\
1.191\end{array}$ & MA & $\begin{array}{l}0.016 \\
1.360\end{array}$ \\
\hline UCE & $\begin{array}{c}0.053 \\
5.380^{* * *}\end{array}$ & ROA & $\begin{array}{c}-0.283 \\
-7.657^{* * *}\end{array}$ & $\begin{array}{c}0.846 \\
46.10^{* * *}\end{array}$ & REM & $\begin{array}{c}-0.022 \\
-3.745^{* * *}\end{array}$ \\
\hline $\mathrm{UCE} * \mathrm{MA}$ & $\begin{array}{c}-0.041 \\
-3.798^{* * *}\end{array}$ & OPCYLCE & $\begin{array}{l}-0.794 \\
-0.797\end{array}$ & $\begin{array}{l}1.217 \\
0.604\end{array}$ & MA $\times$ REM & $\begin{array}{l}0.009 \\
0.558\end{array}$ \\
\hline $\mathrm{CFO}$ & $\begin{array}{c}0.017 \\
2.229^{* *}\end{array}$ & LEV & $\begin{array}{l}0.014 \\
1.196\end{array}$ & $\begin{array}{l}0.007 \\
0.300\end{array}$ & $\mathrm{ROA}$ & $\begin{array}{c}0.188 \\
7.851^{* * * *}\end{array}$ \\
\hline LEV & $\begin{array}{l}-0.001 \\
-0.273\end{array}$ & HIGHNOA & $\begin{array}{c}-0.026 \\
-6.347^{* * *}\end{array}$ & $\begin{array}{l}0.012 \\
1.525\end{array}$ & OPCYLCE & $\begin{array}{c}-8.150 \\
-6.252^{* * *}\end{array}$ \\
\hline OPCYLCE & $\begin{array}{c}5.443 \\
9.842^{* * *}\end{array}$ & $\mathrm{CFO}$ & $\begin{array}{c}-0.918 \\
-70.287^{* * *}\end{array}$ & $\begin{array}{c}-1.243 \\
-47.130^{* * *}\end{array}$ & LEV & $\begin{array}{c}0.060 \\
3.824^{* * *}\end{array}$ \\
\hline $\mathrm{ROA}$ & $\begin{array}{c}-0.094 \\
-9.286^{* * *}\end{array}$ & $\mathrm{C}$ & $\begin{array}{c}0.026 \\
3.030^{* * *}\end{array}$ & $\begin{array}{c}0.196 \\
11.179^{* * *}\end{array}$ & HIGHNOA & $\begin{array}{c}0.033 \\
6.212^{* * *}\end{array}$ \\
\hline BIG & $\begin{array}{c}-0.007 \\
-1.993^{* *}\end{array}$ & & & & $\mathrm{CFO}$ & $\begin{array}{c}0.296 \\
15.343^{* * *}\end{array}$ \\
\hline $\mathrm{C}$ & $\begin{array}{c}0.083 \\
16.97^{* * *}\end{array}$ & & & & $\mathrm{C}$ & $\begin{array}{c}-0.082 \\
-6.795^{* * *}\end{array}$ \\
\hline Year effect & Yes & & Yes & Yes & & Yes \\
\hline Industry effect & Yes & & Yes & Yes & & Yes \\
\hline Adj. $R^{2}$ & 0.60 & & 0.78 & 0.78 & & 0.42 \\
\hline D-W stat. & 1.52 & & 1.802 & 1.851 & & 2.214 \\
\hline F-stat. & 22.80 & & 54.335 & 54.692 & & 11.471 \\
\hline Prob. & 0.000 & & 0.000 & 0.000 & & 0.000 \\
\hline
\end{tabular}

Respectively, the symbols ${ }^{*},{ }^{* *}$, and ${ }^{* * *}$ denote statistical significance at $0.1,0.05$, and 0.01 . The results test classification shifting versus real earnings management in Panel C.

(DA) and nondiscretionay accruals (NDA) by regressing total accruals on the change in sales $(\Delta S)$, change in receiviable accounts $(\triangle \mathrm{REC})$, and property, plant and equipment (PPE), all scaled by lagged total assets, as shown in model (12). We expect that our findings are consistent with Demerjian et al. (2012). Panel B of Table 5 indicates the relationship between managerial ability and other methods of earnings management.

Consistent with the findings of Huang and Sun (2017) [12] and Demerjian et al. (2012) [13], high-ability managers are associated with less use of REM. Also, the managerial ability is not associated with AEM. This result is against the consequence of Demerjian et al. [8, 13].

6.2. Classification Shifting versus Real Earnings Management. Finally, in this study, we investigate how high-ability managerial firms use earnings classification shifting compared to using real earnings management (REM). Zang (2012) believes that managers tend to tradeoff between the earnings management methods [21]; that is, managers can substitute different ways for each other. We employ model (13), which includes the addition of real earnings management (REM) as an independent variable in the model, in order to distinguish the relationship between classification shifting and real earnings management. Also, we include the interaction between the MA and REM variables to indicate whether managerial ability firms represent a similar relationship with all other firms. The results indicate in Panel C of Table 5.

$$
\begin{aligned}
\mathrm{UCE}_{i, t}= & \beta_{0}+\beta_{1} \mathrm{MA}_{i, t}+\beta_{2} \mathrm{REM}_{i, t}+\beta_{3} \mathrm{MA}_{i, t} \times \mathrm{REM}_{i, t} \\
& +\beta_{4} \mathrm{CFO}_{i, t}+\beta_{5} \mathrm{OPCYCLE}_{i, t}+\beta_{6} \mathrm{LEV}_{i, t} \\
& +\beta_{7} \mathrm{ROA}_{i, t}+\beta_{8} \mathrm{HIGHNOA}_{i, t}+\text { Year Effect } \\
& + \text { Industry Effect }+\varepsilon_{i, t} .
\end{aligned}
$$

According to the results, panel $\mathrm{C}$ of Table 5 can show the interaction variable coefficient for $\mathrm{MA} * \mathrm{REM}$ to be 0.009 and is insignificant for the REM measure, respectively. These results show that real earnings management is not used as a substitute for classification shifting when CEO ability exists.

\section{Conclusion}

In this study, we examine the relation between managerial ability and earning classification shifting and also the impact of managerial ability on the relation between REM/UCE and future firm performance. We provide evidence that firms with higher-ability managers have higher earnings classification shifting and lower real earnings management. In the additional tests, we find that high-ability managers clearly choose the real earnings management over classification 
shifting. Furthermore, we find that managers with higherability can reduce the negative impact of earnings management on future performance. Our results also show that there is a significant and negative relationship between highability managers and the agency cost. Moreover, the managerial ability mitigates the impact of earnings management on agency costs.

The conflict between shareholders and managers has occurred since the separation of ownership from management. Agency problems arise when managers manipulate the corporate financial information to achieve their private motivations. The manager's opportunistic behaviors depend on the level of management power and its credit in firms. Disclosure of high-quality information can also be effective in reducing agency costs. Financial disclosure is a mechanism to monitor the activities of managers. When monitoring decreases, managers decide to do their utility, potentially reducing the value of the firm. According to the findings obtained, it can be said that employment of capable managers can decrease their opportunistic behaviors and increase higher-quality earnings. The results highlighting the importance of managers with levels of ability. Therefore, it is suggested that an optimal contract be concluded between firms and capable managers in order to create mutual benefits for both parties.

Since in recent years, the market of Iranian has faced strict economic sanctions; for this reason, the majority of Iranian firms had financial problems. Therefore, it is possible to hide the poor performance of some managers to manage their earnings. Our finding shows that the existence of higher-ability managers is a key factor in firms. Because these managers have higher reasoning and decision power [48] and can use resources effectively and efficiently, therefore, they are less involved in opportunistic behaviors [12]. However, the limitation of this study can be unobservability of some of the managers' decisions on firms' performance; hence, it is difficult to measure managerial ability.

\section{Data Availability}

The data used in this article were obtained from the Codal published by the Iranian Securities and Exchange Organization at https://www.codal.ir/.

\section{Conflicts of Interest}

The authors declare that they have no conflicts of interest regarding the publication of this paper.

\section{References}

[1] M. Imeni, F. Rahnamay Roodposhti, and B. Banimahd, "Relationship real activities manipulation with accrual-based earnings management using recursive equation system approach," Journal of Accounting Knowledge and Management Auditing, vol. 8, no. 29, pp. 1-14, 2019, in Persian.

[2] F.-H. Chen and H. Howard, "An alternative model for the analysis of detecting electronic industries earnings management using stepwise regression, random forest, and decision tree," Soft Computing, vol. 20, no. 5, pp. 1945-1960, 2016.

[3] R. Ball and P. Brown, "An empirical evaluation of accounting income numbers," Journal of Accounting Research, vol. 6, no. 2, pp. 159-178, 1968.

[4] C. Deegan, Financial Accounting Theory, McGraw-Hill Education, New York, NY, USA, 2006.

[5] K. M. Eisenhardt, "Agency theory: an assessment and review," Academy of Management Review, vol. 14, no. 1, pp. 57-74, 1989.

[6] P. Jiraporn, G. A. Miller, S. S. Yoon, and Y. S. Kim, "Is earnings management opportunistic or beneficial? An agency theory perspective," International Review of Financial Analysis, vol. 17, no. 3, pp. 622-634, 2008.

[7] H. Cui, C. Chen, Y. Zhang, and X. Zhu, "Managerial ability and stock price crash risk," Asia-Pacific Journal of Accounting \& Economics, vol. 26, no. 5, pp. 532-554, 2019.

[8] P. R. Demerjian, B. Lev, M. F. Lewis, and S. E. McVay, "Managerial ability and earnings quality," The Accounting Review, vol. 88, no. 2, pp. 463-498, 2013.

[9] S. Rajgopal, T. Shevlin, and V. Zamora, "CEOs' outside employment opportunities and the lack of relative performance evaluation in compensation contracts," The Journal of Finance, vol. 61, no. 4, pp. 1813-1844, 2006.

[10] J. R. Graham, S. Li, and J. Qiu, "Managerial attributes and executive compensation," Review of Financial Studies, vol. 25, no. 1, pp. 144-186, 2012.

[11] S. Bhojraj and P. Sengupta, "Effect of corporate governance on bond ratings and yields: the role of institutional investors and outside directors*," The Journal of Business, vol. 76, no. 3, pp. 455-475, 2003.

[12] X. Huang and L. Sun, "Managerial ability and real earnings management," Advances in Accounting, vol. 39, pp. 91-104, 2017.

[13] P. Demerjian, M. Lewis, and S. McVay, "Managerial ability and earnings management," 2012, https://pdfs. semanticscholar.org/6be4/ 291d367617c6898d459618953f874e73a167.pdf.

[14] C. Skousen, L. Sun, and K. Wu, "The role of managerial ability in classification shifting using discontinued operations," Advances in Management Accounting, vol. 31, pp. 113-131, 2019.

[15] J. Ma and L. Xie, "The comparison and complex analysis on dual-channel supply chain under different channel power structures and uncertain demand," Nonlinear Dynamics, vol. 83, no. 3, pp. 1379-1393, 2016.

[16] Z. Nasrollahi and Z. Arefmanesh, "Investigation of the relationship between ownership and the quality of earnings in tehran stock exchange," Iranian Journal of Accounting Knowledge, vol. 1, no. 3, pp. 117-138, 2011, in Persian.

[17] S. E. McVay, "Earnings management using classification shifting: an examination of core earnings and special items," The Accounting Review, vol. 81, no. 3, pp. 501-531, 2006.

[18] J. L. Abernathy, B. Beyer, and E. T. Rapley, "Earnings management constraints and classification shifting," Journal of Business Finance \& Accounting, vol. 41, no. 6, pp. 600-626, 2014.

[19] R. Ewert and A. Wagenhofer, "Economic effects of tightening accounting standards to restrict earnings management," The Accounting Review, vol. 80, no. 4, pp. 1101-1124, 2005.

[20] D. A. Cohen, A. Dey, and T. Z. Lys, "Real and accrual-based earnings management in the pre- and post-sarbanes-oxley 
periods," The Accounting Review, vol. 83, no. 3, pp. 757-787, 2008.

[21] A. Y. Zang, "Evidence on the trade-off between real activities manipulation and accrual-based earnings management," The Accounting Review, vol. 87, no. 2, pp. 675-703, 2012.

[22] Y. Man, S. Locke, and N. Hewa Wellalage, "Earnings management and agency costs: evidence from China," in Proceedings of the 9th Conference on Financial Markets and Corporate Governance (FMCG), Melbourne, Australia, 2018.

[23] Q. Gao and J. Ma, "Chaos and Hopf bifurcation of a finance system," Nonlinear Dynamics, vol. 58, no. 1, pp. 209-216, 2009.

[24] R. Hesarzadeh, A. Bazrafshan, and J. Rajabalizadeh, "Financial reporting readability: managerial choices versus firm fundamentals," Spanish Journal of Finance and Accounting/Revista Española de Financiación y Contabilidad, vol. 49, no. 4, pp. 452-482, 2019.

[25] A. D. Góis and P. H. N. Parente, "Earnings management by classification shifting and corporate governance in Brazil," BASE-Revista de Administração e Contabilidade da Unisinos, vol. 17, no. 1, pp. 125-151, 2020.

[26] E. O. Boahen and E. C. Mamatzakis, "The impact of religion on classification shifting in the presence of corporate governance and BIG 4 audit," Accounting Forum, vol. 44, no. 2, pp. 103-131, 2020.

[27] E. Wu, "Classification shifting as an earnings management tool among european firms," Master's thesis, Erasmus Universiteit, Rotterdam, Netherlands, 2016.

[28] S. Roychowdhury, "Earnings management through real activities manipulation," Journal of Accounting and Economics, vol. 42, no. 3, pp. 335-370, 2006.

[29] D. A. Cohen and P. Zarowin, "Accrual-based and real earnings management activities around seasoned equity offerings," Journal of Accounting and Economics, vol. 50, no. 1, pp. 2-19, 2010.

[30] M. Noh, D. Moon, and L. Parte, "Earnings management using revenue classification shifting - evidence from the IFRS adoption period," International Journal of Accounting \& Information Management, vol. 25, no. 3, pp. 333-355, 2017.

[31] D. Nissim and S. H. Penman, "Ratio analysis and equity valuation: from research to practice," Review of Accounting Studies, vol. 6, no. 1, pp. 109-154, 2001.

[32] R. G. Sloan, "Do stock prices fully reflect information in accruals and cash flows about future earnings?" The Accounting Review, vol. 71, no. 3, pp. 289-315, 1996.

[33] H. DeAngelo, L. DeAngelo, and D. J. Skinner, "Accounting choice in troubled companies," Journal of Accounting and Economics, vol. 17, no. 1-2, pp. 113-143, 1994.

[34] H. N. Luu, T. N. Doan, and P. T. H. Anh, "Managerial ability and bank failure," Applied Economics Letters, vol. 28, no. 4, 2020.

[35] Y. Luo and L. Zhou, "Managerial ability, tone of earnings announcements, and market reaction," Asian Review of Accounting, vol. 25, no. 4, pp. 454-471, 2017.

[36] G. Shi and L. Zhang, "Managerial ability, layoffs, and unemployment," Applied Economics Letters, vol. 26, no. 21, pp. 1785-1789, 2019.

[37] H. Chen, J. Z. Chen, G. J. Lobo, and Y. Wang, "Effects of audit quality on earnings management and cost of equity capital: evidence from China," Contemporary Accounting Research, vol. 28, no. 3, pp. 892-925, 2011.

[38] H. Ben-Nasr, N. Boubakri, and J.-C. Cosset, "Earnings quality in privatized firms: the role of state and foreign owners,"
Journal of Accounting and Public Policy, vol. 34, no. 4, pp. 392-416, 2015.

[39] P. M. Dechow, "Accounting earnings and cash flows as measures of firm performance," Journal of Accounting and Economics, vol. 18, no. 1, pp. 3-42, 1994.

[40] W. Chi, L. L. Lisic, and M. Pevzner, "Is enhanced audit quality associated with greater real earnings management?" Accounting Horizons, vol. 25, no. 2, pp. 315-335, 2011.

[41] N. Anjum, M. I. Saif, Q. A. Malik, and S. Hassan, "Earnings management and firms' profitability: evidence from Pakistan," European Journal of Economics, Finance and Administrative Sciences, vol. 47, pp. 13-18, 2012.

[42] S. Purkayastha, "Diversification strategy and firm performance: evidence from Indian manufacturing firms," Global Business Review, vol. 14, no. 1, pp. 1-23, 2013.

[43] J. S. Ang, R. A. Cole, and J. W. Lin, "Agency costs and ownership structure," The Journal of Finance, vol. 55, no. 1, pp. 81-106, 2000.

[44] O.-K. Hope and W. B. Thomas, "Managerial empire building and firm disclosure," Journal of Accounting Research, vol. 46, no. 3, pp. 591-626, 2008.

[45] D. W. Diamond and R. E. Verrecchia, "Disclosure, liquidity, and the cost of capital," The Journal of Finance, vol. 46, no. 4, pp. 1325-1359, 1991.

[46] B. A. A. Ghaleb, H. Kamardin, and M. I. Tabash, "Family ownership concentration and real earnings management: empirical evidence from an emerging market," Cogent Economics \& Finance, vol. 8, no. 1, Article ID 1751488, 2020.

[47] P. M. Dechow, R. G. Sloan, and A. P. Sweeney, "Detecting earnings management," The Accounting Review, vol. 70, no. 2, pp. 193-225, 1995.

[48] B. B. Francis, X. Sun, and Q. Wu, "Managerial ability and tax avoidance,” SSRN Electronic Journal, vol. 20, 2013. 